УДК 796.011.3:378

DOI: $\underline{10.35619 / \text { iiu.v1i13.351 }}$

Панчук Ілона старший викладач кафедри теорії і практики фізичної культури і спорту Рівненського державного гуманітарного університету,

м. Рівне, Україна, ORCID: 0000-0003-0518-0701 e-mail: sportclub.rdgu@ukr.net

Панчук Андрій

кандидат педагогічних наук, доцент, доцент кафедри теорії і практики фізичної культури і спорту, Рівненського державного гуманітарного університету, м. Рівне, Україна, ORCID: 0000-0002-1670-5772 e-mail: sportclub.rdgu@ukr.net

Кашуба Анатолій старший викладач кафедри теорії і практики фізичної культури і спорту Рівненського державного гуманітарного університету, м. Рівне, Україна, ORCID: 0000-0001-7782-898X e-mail: Kashuba_A@ukr.net Ковальський Володимир кандидат педагогічних наук, доцент, доцент кафедри теорії і практики фізичної культури і спорту Рівненського державного гуманітарного університету, м. Рівне, Україна, ORCID: 0000-0001-8282-0173 e-mail: sportclub.rdgu@ukr.net

Торчинська Наталія здобувач другого (магістерського) рівня вищої освіти Рівненського державного гуманітарного університету, м. Рівне, Україна, ORCID: 0000-0001-5589-9605 e-mail: torchynska222@gmail.com

\title{
ФІТНЕС-ПРОГРАМИ ДЛЯ ПІДВИЩЕННЯ РУХОВОЇ АКТИВНОСТІ СТУДЕНТІВ: АНАЛІЗ ДОСЛІДЖЕНЬ
}

Анотація. У статті з'ясовано, що один із напрямків сучасної концепції фізичного виховання полягає в досягненні більш вагомих результатів рухової підготовленості на основі реалізації принципово нових підходів, засобів, технологій.. Така діяльність спрямована на ефективне формування у студентів тактично грамотного ставлення до себе і свого тіла, на активізацію потребнісно-мотиваційної сфери, усвідомлення необхідності 


\section{Інноватика у вихованні. Випуск 13.Том 1. 2021.}

зміцнення власного здоров'я, ведення здорового способу життя та системне фізичне удосконалення.

Аналіз досліджень засвідчує, що складовою частиною гармонійного розвитку особистості є взаємодія фізичного та естетичного виховання, що поєднує в собі фізичні та духовні якості. Використання засобів фізичної культури у цьому напрямку значною мірою буде пов'язане із застосуванням фізкультурно-оздоровчих програм. При складанні програм оздоровчої спрямованості враховуються загальні закономірності навчання руховим діям і розвитку фізичних якостей, а також особливості методики фізичного виховання студентського контингенту.

3'ясовано, що реалізація різноманітних фізкультурно-оздоровчих завдань стала поштовхом для розробки і створення нових видів рухової активності. Фітнес-програми $є$ практичним проявом фізкультурнооздоровчих технологій у фізичному вихованні. Вони побудовані так, щоб задовольнити психологічні потреби, зняти втому, сприяти покращенню серцево-судинної системи, розвитку фізичних якостей. Але, як зазначає низка авторів, метою ідеальної оздоровчої системи має бути всебічний розвиток функцій організму як необхідна умова здоров'я. Одним зі специфічних завдань є оптимізація фізичного розвитку, удосконалення рухових здібностей, зміцнення і збереження здоров'я. Комплексність взаємодії як методичний принцип пропонує одночасний вплив на психофізичну сферу, функціональні системи, рухові здібності та інтелект.

Ключові слова: оздоровчі фітнес-програми, підвищення рухової активності, фізичне виховання, аеробіка, студенти.

Постановка проблеми. Нині вченими ведуться пошуки нових підходів до складання фізкультурно-оздоровчих програм 3 метою підвищення ефективності впливу фізичного виховання; визначаються більш результативні форми організації діяльності студентів та здійснюються розвідки нових методів i засобів, що активізують зацікавленість здобувачів не тільки до занять фізичної культури, а й формують потребу та уміння самостійно займатися фізичними вправами; опрацьовуються питання оптимізації рухових режимів та покращення рівня фізичної підготовленості, дозування фізичних навантажень 3 урахуванням психофізіологічних, типологічних та соціальних особливостей студентів.

Особливої актуальності набуває розробка програм занять оздоровчої фізичної культури $з$ використанням її найбільш раціональних і доступних засобів i методів. Характерною рисою фітнес-програм $\epsilon$ широке використання вправ стато-динамічного характеру (йоги, пілатес, тай-чі), а також вправи з ускладненими умовами опори (фітбол, кор-тренування). Це сприяє розвитку рівноваги завдяки інстинктивному включенню в роботу м'язів, які забезпечують утримання правильної постави (Булич та Кобза, 2000). 


\section{Інноватика у вихованні. Випуск 13.Том 1. 2021.}

Аналіз останніх досліджень 3 проблеми. Незважаючи на численні дослідження в цій сфери фізичного виховання, актуальною залишається проблема пошуку ефективних програм, методик і технологій підвищення рухової активності студентів з метою покращення стану їхнього здоров’я та вдосконалення фізичної підготовленості завдяки впровадженню таких сучасних фізкультурно-оздоровчих фітнес-технологій, які $б$ сприяли розвитку позитивної мотивації до занять фізичною культурою, формували основи самостійної оздоровчої діяльності як у системі освіти у закладі вищої освіти, так і у вільний час. Останнім часом з'являються універсальні фітнес-програми, які орієнтовані на окремі групи населення, зокрема і на студентську молодь. Такі фітнес-програми приваблюють своєю доступністю, варіативністю навантаження, емоційністю i можливістю змінювати зміст занять залежно від інтересів та підготовленості тих, хто займається.

Автори оздоровчих фітнес-програм, спрямованих на розвиток рухових здібностей, Боднар I., Колесень А., Хозяінова Д. стверджують, що основними компонентами є зміцнення здоров'я, сприяння нормальному розвитку рухових i координаційних здібностей, виховання вольових якостей, навчання життєво важливим руховим умінням і навичкам, набуття необхідних знань у сфері фізичної культури і спорту, сприяння всебічному та гармонійному розвитку особистості, виховання свідомої потреби займатися фізичними вправами, підвищення працездатності.

Мета дослідження - теоретично обгрунтувати застосування оздоровчих фітнес-програм для підвищення рухової активності студентів закладів вищої освіти.

Виклад основного матеріалу дослідження. На сьогодні існують три різновиди програм оздоровчих занять. Перший передбачає використання вправ аеробного характеру, які виконуються безперервним методом упродовж 10-30 хв. Вважається, що найбільш ефективні аеробні вправи низької або помірної інтенсивності.

Наступний різновид програми передбачає використання вправ силового та швидкісно-силового характеру, інтервали роботи складають від 15 сек. до 3 хв. і чергуються з періодами відпочинку такої ж тривалості. Такі заняття проводяться за допомогою колового методу.

У третьому випадку в програмах використовується комплексний підхід, який передбачає використання різноманітних вправ, що перераховані вище.

За даними літературних джерел перевага надається використанню фізичних навантажень аеробної спрямованості. В умовах техногенного розвитку цивілізації в цілому і суспільства зокрема, сучасна людина зазнає негативного впливу гіпокінезії, гіподинамії, соціальної нестабільності, що $\epsilon$ причиною широкого розповсюдження захворювань кардіо-респіраторної системи. Низька оздоровча ефективність фізичного виховання пояснюється відсутністю необхідної мотивації та інтересу до стану свого здоров’я та фізичної підготовленості. У зв’язку з цим в сучасних фітнес- 


\section{Інноватика у вихованні. Випуск 13.Том 1. 2021.}

програмах вагоме місце відводиться засобам, які сприяють розвитку структурно-функціонального потенціалу цих систем, що забезпечує їх високу резистентність щодо вищезазначених чинників. Тому використання аеробних програм і $\epsilon$ найбільш ефективними для зниження факторів ризику серцево-судинних захворювань, покращенню форми тіла та координації рухів, що дає довгостроковий позитивний ефект для самооцінки та психічного стану в цілому (Кібальник, 2007).

У роботах дослідників висвітлені особливості методики побудови фізкультурно-оздоровчих занять для розвитку силових здібностей. Вони схиляються до думки, що фітнес-програми повинні бути спрямовані на розвиток двох основних якостей, які взаємопов'язані з фізичним здоров'ям студентів - це сила та витривалість (Боднар, 1999; Войтенко, 1991).

Але, як зазначає низка авторів, метою ідеальної оздоровчої системи повинен бути всебічний розвиток функцій організму як необхідної умови здоров’я. Одним зі специфічних завдань $є$ оптимізація фізичного розвитку, удосконалення рухових здібностей, зміцнення і збереження здоров'я. Комплексність взаємодії як методичний принцип пропонує одночасний вплив на психофізичну сферу, функціональні системи, рухові здібності та інтелект. Організм людини оптимально функціонує, якщо узгоджена робота його органів та систем. Будь-який дисбаланс, безперечно, призводить до погіршення оздоровчого потенціалу організму.

Для розвитку та формування гармонійно-розвиненої особистості важливе значення має організація фізкультурно-оздоровчих занять, які використовуються 3 метою удосконалення певних якостей, самозадоволення особистих потреб. Тренування, спрямоване на однобічний розвиток певної функції, нерідко стає причиною виникнення патологічних станів. 3 огляду на те, що основною метою фітнес-програм $\epsilon$ досягнення оздоровчого ефекту, вони повинні передбачати створення умов для гармонійного розвитку усіх систем організму та фізичних якостей (Козіброцький, 2002).

Наприклад, О. С. Губарєва (2001) розробила педагогічну технологію підвищення рухової активності. Вона вивчила вплив різних видів аеробіки на організм людини і запропонувала використовувати комплексний підхід у фізкультурно-оздоровчих заняттях. Розроблена нею уніфікована методика «Фітнес - Мікс» для жінок складається 3 блоків різної спрямованості.

Також наголошується на актуальності розробки фітнес-програм для дівчат на основі аеробіки, яка проводилася в позааудиторній формі навчання (Канішевський, 1999). 3 метою системного підходу до оптимізації фізичного виховання та фізкультурно-оздоровчої роботи Г. В. Глоба (2007) пропонувала інноваційну програму, що поєднувала традиційний зміст державної програми з фізичної культури з сучасною, спеціально розробленою системою фізкультурно-оздоровчої роботи 3 використанням аеробних технологій. У свою чергу дослідники займалися програмуванням фізкультурно-оздоровчих занять для дівчат 3 


\section{Інноватика у вихованні. Випуск 13.Том 1. 2021.}

урахуванням фізичного здоров'я та пропонували впровадити їх у позааудиторних формах навчання. Виходячи 3 необхідності цілеспрямованого удосконалення координаційних здібностей дівчат 18 19 років, Д. Хозяіновою (2004) створена методика, в основі якої один 3 найпопулярніших видів оздоровчої фізичної культури - аеробіка 3 урахуванням тілобудови та біологічного віку.

У широкому уявленні аеробіка - це система вправ, спрямованих на розвиток аеробних можливостей енергозабезпечення рухової активності. Загальновідомо, що біг, ходьба, танці, плавання, заняття на кардіотренажерах використовуються у якості засобів впливу на діяльність серцево-судинної та дихальної систем, що характеризують рівень аеробної продуктивності та значною мірою визначають стан фізичного здоров'я людини (Бакурідзе-Маніна, 2003).

Не слід сприймати термін «аеробіка» як заняття фізичними вправами тільки в аеробному режимі. Це ефективне, цілісне, довготривале тренування, під час якого центральним пунктом $\epsilon$ важливі фітнескомпоненти, зокрема такі, як сила, гнучкість та координація в тісному взаємозв'язку 3 музикою, злиті в одну єдину логічно побудовану тренувальну програму. На думку Н. Чухланцевої (2010), «аеробіка поточне виконання вправ танцювально-гімнастичного характеру, що сприяють вихованню загальної витривалості».

У працях зустрічається термін «оздоровча аеробіка», який розглядається як один із напрямів масової фізичної культури з регулярним навантаженням, що синтезує елементи фізичних вправ, танцю і музики. Музичний супровід - незамінна частина великої кількості сучасних напрямів в аеробіці (Долженко, 2013).

3 розвитком та поширенням аеробіки з'являються нові фітнеспрограми. До характерної в наш час тенденції активного розширення засобів рекреації і оздоровчої фізичної культури належить і система нетрадиційних вправ 3 використанням спеціалізованих тренажерів під назвою «Аеробна велокінетика», «Спінінг», «Сайк Рібок», «Спінбайк».

Технологія комплексних вправ «Спінінгу», що грунтується на модернізації велотренування в залі за допомогою спеціалізованого тренажера, дозволяє, поряд 3 основним видом тренувальної роботи педалюванням, використовувати різноманітні варіанти рухів за участю м'язів суглобів тулуба та верхнього плечового пояса. Система аеробної велокінетики «Спінінг» являє собою комплекс модифікованих вправ на тренажерах, які виконуються груповим методом 3 музичним супроводом (Колокатова, 2008, с.134).

До занять на розвиток аеробної витривалості можна віднести степаеробіку, програму «Total Body Workout», хай-імпакт, хай-лоу-імпакт, роуп-скіппінг. Сучасні фітнес-програми містять великий діапазон тренувальних засобів, що дозволяють вирішувати різні задачі: посттравматичної реабілітації, поетапного кондиційного тренування, високоінтенсивного спортивного тренування 3 елементами атлетизму. 


\section{Інноватика у вихованні. Випуск 13.Том 1. 2021.}

Силова аеробіка грунтується на використанні різноманітного інвентарю: бодібарів, гантелей, амортизаторів, а також такого спортивного обладнання, як поперечини, міні-штанги, гантелі (памп-аеробіка).

Система Пілатеса містить серію вправ, спрямованих переважно на м'язи живота, особливо на їх глибинний шар. У методиці Пілатеса особливе значення приділяється концентрації уваги і правильному диханню. Система являє собою програму комплексного оздоровлення тіла, духу і розуму. Це більше ніж серія рухів, і може бути адаптована до індивідуальних потреб (Романова, 2010).

Фітнес-програми, як форми рухової активності, мають як оздоровчокондиційну спрямованість (загартування, підтримка належного рівня фізичного стану), так і можуть бути пов'язані із складнішими завданнями щодо вирішення спортивних завдань на досить високому рівні. Подібні фітнес-програми орієнтовані на цілі оздоровчого фітнесу, а також мають спортивно-орієнтовне спрямування (Дубинська, Петренко, 2016).

Висновки і перспективи подальших розвідок. Отже, аналізуючи науково-методичну літературу, ми з'ясували, що існує безліч фізкультурно-оздоровчих програм, які спрямовані на розв'язання різноманітних завдань, але не виявлено фітнес-програми як ефективного засобу підвищення рухової активності, яка б задовільняла інтереси та захоплення не тільки дівчат, а й хлопців.

Тому, аналіз науково-методичної літератури дозволив визначити ряд проблемних питань. По-перше - рівень рухової активності та фізичної підготовленості студентів останніми роками має тенденцію до зниження, причиною чого $є$ як техногенні фактори, так і низька зацікавленість студентів у заняттях фізичною культурою. По-друге - існуючих підходів до програмування фізкультурно-оздоровчих занять зі студентами недостатньо, що викликає необхідність урізноманітнення засобів фізичного виховання студентів. По-третє - існує необхідність оновлення змісту програми фізичного виховання студентської молоді завдяки застосуванню видів рухової активності, що відповідають їх інтересам.

На сьогодні практично відсутні науково-методичні розробки, які б дозволяли комплексно використовувати сучасні види рухової активності у процесі фізкультурно-оздоровчих занять зі студентами залежно від вікових особливостей, фізичної підготовленості, статевих відмінностей у формуванні мотиваційних пріоритетів, які сприяли б розвитку позитивної мотивації до занять фізичною культурою, формували основи самостійної оздоровчої діяльності та формували прагнення до здорового способу життя.

Перспективу подальших досліджень вбачаємо у експериментальному дослідженні проведення занять 3 фітнесу студентами закладів вищої освіти. 


\section{Інноватика у вихованні. Випуск 13.Том 1. 2021.}

\section{СПИСОК ВИКОРИСТАНИХ ДЖЕРЕЛ}

Булич, Е. и Кобза, М. (2000). Влияние занятий спортом на здоровье и адаптацию организма студентов к физическим загрузкам. Олімпійський спорт і спорт для всіх: проблеми здоров 'я, рекреаиії, спортивної медицини mа реабілітації: Тези доп. IV Міжнар. наук. конгр. К. С. 344-346.

Кібальник, О. (2007). Оздоровчі технології для підвищенні рухової активності підлітків. Теорія та методика фізичного виховання і спорту. № 4. CC. 63-66.

Боднар, I. (1999). Особиста фізична культура студентів 3 низьким рівнем фізичної підготовленості. Науковий вісник Волинського державного університету. Луцьк: ВДУ ім. Лесі Українки, № 2. СС. 13-21.

Войтенко, В. (1991). Здоровье здоровых: Введение в санологию. Київ: Здоров'я. 245 с.

Козіброцький, С. (2002). Програмно-нормативні основи фізичного виховання студентів. Кандитат наук з фізичного виховання і спорту. Львів, $16 \mathrm{c}$.

Губарева, О. (2001). Розробка та обгрунтування уніфікованої методики занять оздоровчої гімнастики для жінок «Фітнес-мікс». Теорія $i$ методика фізичної культури і спорту. № 1. СС. 3-6.

Канішевський, С. (1999). Науково-методичні та організаційні основи фізичного самовдосконалення студентства. К.: ІЗМН, 270 с.

Глоба, Г. (2007). Інноваційна система фізичного виховання школярів з використанням аеробних технологій. Кандидат наук 3 фізичного виховання і спорту. Харків, $21 \mathrm{c.}$

Хозяинова, Д. (2004). Совершенствования координационных способностей девочек 14-15 лет средствами аэробики с учетом типа телосложения. Кандидат педагогических наук. Омск. 23 с.

Бакурідзе-Маніна, В. (2003). Оцінка впливу традиційних занять 3 фізичного виховання на функціональний стан, рухові можливості студенток 3 низькими фізкультурно-спортивними інтересами. Слобожанський науково-спортивний вісник. № $6.21 \mathrm{c}$.

Чухланцева, Н. (2010). Оптимізація прочесу фізичного виховання студентів транспортних спеціальностей на основі поглибленого курсу професійно-прикладної фізичної підготовки. Кандидат наук з фізичного виховання і спорту. Харків: Харківська державна академія фізичної культури. 22 с.

Долженко, Л. (2013). Належний рівень розвитку рухових якостей студентської молоді. Фізична культура, спорт та здоров'я нації: збірник наукових праџь. Вінницький державний педагогічний університет ім. Михайла Коцюбинського. Вінниця: ТОВ «Ландо ЛТД», Вип. 15. СС. 8286.

Колокатова, Л. (2008). Дидактическая система информационной поддержки психофизической подготовки студентов технических вузов. Доктор педагогических наук. Москва, 50 с. 


\section{Інноватика у вихованні. Випуск 13.Том 1. 2021.}

Романова, В. (2010). Динаміка фізичної підготовленості студенток старших курсів вищих навчальних закладів на основі різних режимів рухової активності. Кандидат наук 3 фізичного виховання і спорту. Харків. 20 с.

Дубинська, О. та Петренко Н. (2016). Сучасні-фітнес технологї у фізичному вихованні учнівської $і$ студентської молоді: проектування, розробка, специфічні особливості : монографія. Суми: Вид-во СумДПУ імені А. С. Макаренка, 566 с.

\section{REFERENCES}

Bulych, E. \& Kobza, M. (2000). Vlianiye zanyatiy sportom na zdorove i adaptatsyu organizma studentov k fizicheskim zagruzkam. [Influence of sports on health and adaptation of an organism of students to physical activities]. Olimpiiskyi sport i sport dlia vsikh: problemy zdorovia, rekreatsii, sportyvnoi medytsyny ta reabilitatsii: V: Tezy dop. IV Mizhnar. nauk. konhr. K. SS. 344346. [in Russian].

Kibalnyk, O. (2007). Ozdorovchi tekhnolohii dlia pidvyshchenni rukhovoi aktyvnosti pidlitkiv. [Health-improving technologies for increase of motor activity of teenagers]. Teoriia ta metodyka fizychnoho vykhovannia i sportu. No 4. SS. 63 - 66. [in Ukrainian].

Bodnar, I. (1999). Osobysta fizychna kultura studentiv z nyzkym rivnem fizychnoi pidhotovlenosti. [Personal physical culture of students with a low level of physical preparation]. Naukovyi visnyk Volynskoho derzhavnoho universytetu. Lutsk: VDU im. Lesi Ukrainky, No 2. SS. 13-21. [in Ukrainian].

Voitenko, V. (1991). Zdorove zdorovykh: Vvedeniye v sanologiyu [Health of the healthy: Introduction to sanology]. K.: Zdorovia. $245 \mathrm{~s}$. [in Ukrainian].

Kozibrotskyi, S. (2002). Programno-normatyvni osnovy fizychnoho vykhovannia studentiv. [Program-normative bases of physical education of students]. Kandytat nauk z fizychnoho vykhovannia i sportu. Lviv, 16 s. [in Ukrainian].

Hubareva, O. (2001). Rozrobka ta obgruntuvannia unifikovanoi metodyky zaniat ozdorovchoi himnastyky dlia zhinok "Fitnes-miks". Teoriia i metodyka fizychnoi kultury i sportu. No 1. SS. 3 - 6. [in Ukrainian].

Kanishevskyi, S. (1999). Naukovo-metodychni ta orhanizatsiini osnovy fizychnoho samovdoskonalennia studentstva. [Scientific-methodical and organizational bases of physical self-improvement of students]. K.: IZMN, 270 s. [in Ukrainian].

Hloba, H. (2007). Innovatsiina systema fizychnoho vykhovannia shkoliariv $z$ vykorystanniam aerobnykh tekhnolohii. [Innovative system of physical education of schoolchildren with the use of aerobic technologies]. Kandydat nauk z fizychnoho vykhovannia i sportu. Kharkiv, $21 \mathrm{~s}$. [in Ukrainian].

Khoziaynova, D. (2004). Sovershenstvovaniya koordinatsionnykh sposobnostei devochek 14-15 let sredstvami aerobiki $s$ uchetom tipa teloslozheniya [Perfection of coordination abilities of 14 - 15 aged girls by means 


\section{Інноватика у вихованні. Випуск 13.Том 1. 2021.}

of aerobics taking into account a type of a physique]. Kandidat pedagogicheskikh nauk. Omsk. 23 s. [in Russian].

Bakuridze-Manina, V. (2003). Otsinka vplyvu tradytsiinykh zaniat z fizychnoho vykhovannia na funktsionalnyi stan, rukhovi mozhlyvosti studentok z nyzkymy fizkulturno-sportyvnymy interesamy. [Assessment of the impact of traditional physical education classes on the functional state, motor abilities of students with low physical culture and sports interests]. Slobozhanskyi naukovosportyvnyi visnyk. No $6.21 \mathrm{~s}$. [in Ukrainian].

Chukhlantseva, N. (2010). Optymizatsiia protsesu fizychnoho vykhovannia studentiv transportnykh spetsialnostei na osnovi pohlyblenoho kursu profesiinoprykladnoi fizychnoi pidhotovky. [Optimization of the process of physical education of students of transport specialties on the basis of an in-depth course of professional and applied physical training]. Kandydat nauk z fizychnoho vykhovannia i sportu. Kh.: Kharkivska derzhavna akademiia fizychnoi kultury. 22 s. [in Ukrainian].

Dolzhenko, L. (2013). Nalezhnyi riven rozvytku rukhovykh yakostei studentskoi molodi. [Appropriate level of development of motor qualities of student youth]. Fizychna kultura, sport ta zdorovia natsii: zbirnyk naukovykh prats. Vinnytskyi derzhavnyi pedahohichnyi universytet im. Mykhaila Kotsiubynskoho. Vinnytsia: TOV "Lando LTD", Vyp. 15. SS. 82 - 86. [in Ukrainian].

Kolokatova, L. (2008). Didakticheskaia sistema informatsionnoy podderzhki psikhofizicheskoy podgotovky studentov tekhnicheskikh vuzov. [Didactic system of information support of psychophysical training of students of technical high schools]. Doktok pedagogicheskikh nauk. M., 50 s. [in Russian].

Romanova, V. (2010). Dynamika fizychnoi pidhotovlenosti studentok starshykh kursiv vyshchykh navchalnykh zakladiv na osnovi riznykh rezhymiv rukhovoi aktyvnosti. [Dynamics of physical fitness of senior students of higher educational institutions on the basis of different modes of motor activity]. Kandydat nauk z fizychnoho vykhovannia i sportu. Kh. 20 s. [in Ukrainian].

Dubinska, O. \& Petrenko N. (2016). Suchasni-fitnes tekhnolohii u fizychnomu vykhovanni uchnivskoi $i$ studentskoi molodi: proektuvannia, rozrobka, spetsyfichni osoblyvosti : monohrafiia. [Modern fitness technologies in physical education of pupils and students: design, development, specific features]. Sumy: Vyd-vo SumDPU imeni A. S. Makarenka, 566 s. [in Ukrainian]. 


\section{FITNESS PROGRAMS FOR INCREASING MOTIONAL ACTIVITY OF STUDENTS: ANALYSIS OF RESEARCH}

Ilona Panchuk

Senior Lecturer at the Department of Theory and Practice of Physical Culture and Sports Rivne State University for the Humanities,

Rivne, Ukraine ORCID: 0000-0003-0518-0701 e-mail: sportclub.rdgu@ukr.net

Andrii Panchuk Candidate of Pedagogical Sciences, Associate Professor at the Department of Theory and Practice of Physical Culture and Sports Rivne State University for the Humanities,

Rivne, Ukraine ORCID: 0000-0002-1670-5772 e-mail: sportclub.rdgu@ukr.net

Anatolii Kashuba

Senior Lecturer at the Department of Theory and

Practice of Physical Culture and Sports Rivne State University for the Humanities,

Rivne, Ukraine ORCID: 0000-0001-7782-898X e-mail: sportclub.rdgu@ukr.net Volodymyr Kovalskyi Candidate of Pedagogical Sciences, Associate Professor at the Department of Theory and Practice of Physical Culture and Sports Rivne State University for the Humanities,

Rivne, Ukraine ORCID: 0000-0001-8282-0173 e-mail: sportclub.rdgu@ukr.net

Nataliia Torchynska Applicant for the Second (Master's) Level of Higher Education Rivne State University for the Humanities, Rivne, Ukraine ORCID: 0000-0001-5589-9605 e-mail: torchynska222@gmail.com

\footnotetext{
Abstract. The article states that one of the directions of the modern concept of physical education is to achieve more significant results of motional training based on the implementation of fundamentally new approaches, tools, technologies, to intensify the need-motivational sphere, awareness of the need
} 


\section{Інноватика у вихованні. Випуск 13.Том 1. 2021.}

to strengthen their own health, lead a healthy lifestyle and systemic physical improvement.

Analysis of research shows that an integral part of the harmonious development of personality is the interaction of physical and aesthetic education, which combines physical and spiritual qualities. The use of physical culture in this direction is associated with the use of fitness programs. When compiling health programs, the general laws of learning motor actions and the development of physical qualities, features of the methods of physical education of the student body are taken into account.

It was found that the implementation of various physical culture and health tasks has led to the development and creation of new types of physical activity. Fitness programs are a practical manifestation of physical culture and health technologies in physical education. They are built in such a way as to satisfy psychological needs, relieve fatigue, help improve the cardiovascular system, the development of physical qualities. But based on the authors' thoughts, the goal of an ideal health system should be the comprehensive development of body functions as a necessary condition for health. One of the specific tasks is to optimize physical development, improve motor skills, strengthen and maintain health. The complexity of interaction, as a methodological principle, offers a simultaneous impact on the psychophysical sphere, functional systems, motor abilities and intelligence.

Keywords: health fitness programs, increase of physical activity, physical education, aerobics, students.

Стаття надійшла до редакиії 18.05.2021 p. 